\title{
Efficacy of Different Anti-bacterial Medicaments for Treatment of Equine Endometritis
}

\author{
Abou El-Amaiem $\mathbf{W}^{1^{*}}$, El-Desouki $\mathbf{M}^{2}$, Eldesouky $\mathrm{A}^{2}$ and Motaser $\mathrm{A}^{2}$ \\ ${ }^{1}$ Aga District Veterinary Authority, Dakahlia Governorate, Egypt \\ ${ }^{2}$ Theriogenology Department, Faculty of Veterinary Medicine, Mansoura University, Egypt
}

"Corresponding author: Abou El-Amaiem W, Aga District Veterinary Authority, Dakahlia Governorate, Egypt, +251-912-82-82-53; Fax: +2-050-6432888; E-mail: waleedabouelamaim@gmail.com

Rec date: Nov 07, 2015; Acc date: Dec 23, 2015; Pub date: Dec 25, 2015

Copyright: @ 2015 Amaiem AEW, et al. This is an open-access article distributed under the terms of the Creative Commons Attribution License, which permits unrestricted use, distribution, and reproduction in any medium, provided the original author and source are credited.

\begin{abstract}
This study aimed to study the Efficacy of different anti-bacterial medicaments for treatment of equine endometritis. This study was carried out on 67 mares of varying ages (average age was 5 years old) from February 2012 to December 2013. They were diagnosed to be affected with endometritis by case history, clinical examination, ultrasonographic examination, low volume uterine flush and cytological examination of the uterine flush. The affected animals were then randomly classified into four groups; the 1st group was treated by intra-uterine wash with saline only (control), the 2nd group was treated by intra-uterine wash with saline supplied with gentamicin $10 \%$, the 3rd group was treated by intra uterine wash with saline supplied with Cefepime, while the 4th group treated by Ceftiofur systemically. The results showed that there was a significant variation $(P<0.05)$ between groups treated by intra uterine wash with saline supplied with Cefepime (3rd group), and which was treated by intra uterine wash with saline only (control group) in both conception and pregnancy rates where the 3rd group showed the highest conception and pregnancy rates and the control group gave the lowest ones. In conclusion, Cefepime is the most appropriate antibiotic for treatment of endometritis in mares.
\end{abstract}

Keywords: Antibacterial; Cefepim; Endometritis; Mares

\section{Introduction}

Endometritis has long been recognized as a major cause of reduced fertility in mares. There are several sources of uterine contamination that enhance development of endometritis including parturition, reproductive examination, artificial insemination or natural breeding [1].

Endometritis in mare is an acute or chronic inflammation of the endometrium and its associated cellular components and structures. Typically in the mare, the inflammation does not extend deeper than the endometrial layer. More extensive inflammation of uterine tissues (i.e., metritis or perimetritis) may be encountered in postpartum mares [2].

There are various ways used for diagnosis of a case of endometritis, these including; case history, clinical and physical examination, vaginal examination, rectal palpation, trans-rectal ultrasonography, uterine culture, cytologic examination and endoscopy. Also, there are different methods to treat endometritis in mare, this include: exercise and intrauterine lavage, intra-uterine wash with antibiotics and systemically injected antibiotics [3].

According to our knowledge there were scare research papers on treatment of endometritis in mares in Egypt so, the present study aimed to assess different antibacterial medicaments used for treatment of endometritis in mares in Egypt.

\section{Material and Methods}

\section{Animals}

The present study was carried out from February 2012 to December 2013 on a number of 67 mares of varying ages and from different localities that includes: 1) Thirty-seven Arabian mares from Al-Zahraa farm in Cairo, 2) Thirty-one working mares in Dakahlia and Gharbeya governorates.

\section{Ultrasonographical examination}

Ultrasonographic examination of affected animals was done by using of ultrasound machine (Chison 8300, CHISON MEDICAL IMAGING CO., LTD, China) with trans-rectal (5 MHZ) linear transducer looking for presence of intrauterine fluid as described by Brinsko et al. [4] (Figure 1).

\section{Low-volume fluid uterine wash and cytological examination}

A $50 \mathrm{ml}$ of sterile sodium chloride $0.9 \%$ solution (Otsoka Co.) was used for uterine wash of affected animals. The recovered fluid from the uterine wash was examined for the presence of Polymorphonuclear cells (PMNs) by using Giemsa stain as mentioned by Kawthalkar [5]. The cytologic picture revealed the presence of large number of (PMNs) relative to endometrial cells (more than two PMNs at $100 \mathrm{X}$ magnification field) [6].

Experimental design: The affected animals were classified into four groups as the following:

Control group: Fifteen mares received normal saline solution $(\mathrm{NaCl}$ $0.9 \%)$ pre-warmed to $40 \mathrm{o} \mathrm{C}$ as uterine wash. 
Citation: Amaiem AEW, Desouki EM, Eldesouky A, Motaser A (2016) Efficacy of Different Anti-bacterial Medicaments for Treatment of Equine

Page 2 of 3

Gentamicin group: Sixteen mares were treated with $(500 \mathrm{ml}$ normal saline) supplied with gentamicin 10\% (Gentapex, SP Veterinaria Company, Spain) buffered with equal amount of sodium bicarbonate (NaHCO3 7.5\%) to avoid irritation.

Cefepime group: Sixteen mares were treated with $(500 \mathrm{ml}$ normal saline) supplied with Cefepime (Maxipime 2 gram vial, Glaxosmith Kline Company, Egypt).

Ceftiofur group: Twenty mares were treated with Ceftiofur crystalline free acid (Exceed, Pfizer Company, Egypt) for Intramuscular injection.

Statistical analysis: Data were collected, organized, summarized and then statically analyzed by using Graphpad prism software. One way analysis of variance (ANOVA) was used. P-value was set at 0.05 and 0.001 to determine the level of significance according to SAS [7].

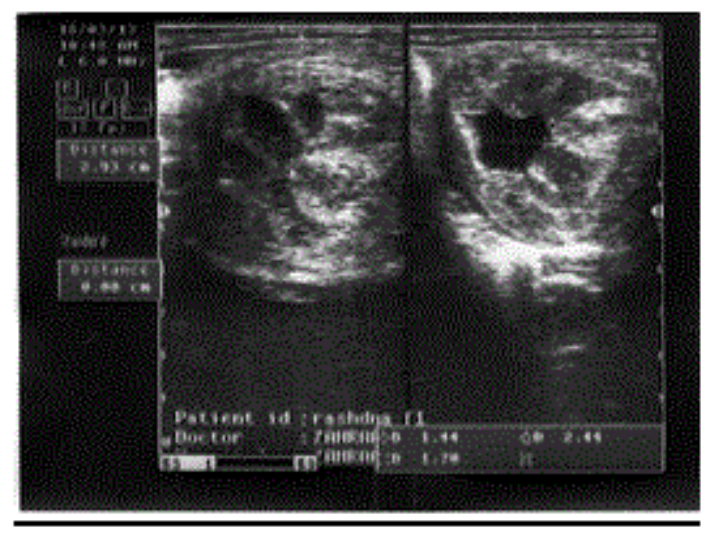

Figure 1: Ultrasonographic examination of a mare uterus, a transverse section of the uterine horn showing (anechogenic) lumen. This picture can be interpreted with the presence of intrauterine fluid (grade I).

\section{Results}

As shown in Tables 1 and 2 Cefepime (group 3) had a significantly higher conception rate $(87.5 \%)$ in comparison to the other groups.

As shown in Table 3, Cefepime (group 3) had a significantly higher pregnancy rate $(75 \%)$ in comparison to the other groups.

\begin{tabular}{|l|l|l|l|l|}
\hline \multicolumn{2}{|l|}{ Group of mares } & $\begin{array}{l}\text { Treated } \\
\text { animals }\end{array}$ & $\begin{array}{l}\text { Conceived } \\
\text { animals }\end{array}$ & $\begin{array}{l}\text { Conception } \\
\text { rate (\%) }\end{array}$ \\
\hline Control group (saline) & Intra-uterine & 15 & 6 & 40 \\
\hline $\begin{array}{l}\text { Gentamicin } 10 \%+ \\
\text { NaHCO3 } 7.5 \%\end{array}$ & Intra-uterine & 16 & 9 & 56.25 \\
\hline $\begin{array}{l}\text { Cefepime } \\
\text { (Maxipime 2 gm) }\end{array}$ & Intra-uterine & 16 & 14 & 87.5 \\
\hline Ceftiofur (Exceed) & systemic I.M. & 20 & 14 & 70 \\
\hline
\end{tabular}

Table 1: (Conception rate).

\begin{tabular}{|l|l|l|l|l|}
\hline \multicolumn{2}{|l|}{ Group of mares } & $\begin{array}{l}\text { Treated } \\
\text { animals }\end{array}$ & $\begin{array}{l}\text { pregnant } \\
\text { animals }\end{array}$ & $\begin{array}{l}\text { Pregnancy } \\
\text { rate (\%) }\end{array}$ \\
\hline Control group (saline) & Intra-uterine & 15 & 4 & 26.66 \\
\hline $\begin{array}{l}\text { Gentamicin } 10 \%+ \\
\text { NaHCO3 } 7.5 \%\end{array}$ & Intra-uterine & 16 & 6 & 37.5 \\
\hline $\begin{array}{l}\text { Cefepime } \\
\text { (Maxipime 2 gm) }\end{array}$ & Intra-uterine & 16 & 12 & 75 \\
\hline Ceftiofur (Exceed) & systemic I.M. & 20 & 12 & 60 \\
\hline
\end{tabular}

Table 2: (Pregnancy rate).

\begin{tabular}{|l|l|l|l|l|}
\hline \multicolumn{2}{|l|}{ Group of mares } & $\begin{array}{l}\text { 1st estrous conception rates } \\
(\%)\end{array}$ & $\begin{array}{l}\text { 2nd estrous conception rates } \\
\text { (\%) }\end{array}$ & $\begin{array}{l}\text { 3rd estrous conception rates } \\
\text { (\%) }\end{array}$ \\
\hline Control group (saline) & Intra-uterine & 0 & 6.667 & 33.33 \\
\hline Gentamicin 10\%+ NaHCO3 7.5\% & Intra-uterine & 0 & 25 & 31.25 \\
\hline Cefepime (Maxipime 2 gm) & Intra-uterine & 12.5 & 12.5 & 62.5 \\
\hline Ceftiofur (Exceed) & systemic I.M. & 55 & 15 & 0 \\
\hline
\end{tabular}

Table 3: (1st, 2nd and 3rd estrous conception rates).

\section{Discussion}

The results of 1st group showed that the number of cured mares that return to its normal fertility life was 6 (conception rate was $40 \%)$. The number of mares that retain their pregnancy was 4 (pregnancy rate was $26.66 \%$ ). These mares that retain their pregnancies may cure due to leaving the mares several cycles in a sexual rest that allow the endometrium to regain its normal vitality. This was approved by Troedsson [8] who mentioned that the use of antibiotics may not be necessary, even in cases of bacterial contamination, if the mares were treated by large volume lavage and/or ecbolic agents within $12 \mathrm{hrs}$ of mating.

The results of 2nd group (gentamicin) revealed that the number of cured mares that return to its normal fertility life was 9 (conception rate was $56.25 \%$ ). This low conception rate was approved by; Cohen [9], Gibbons [10], Siu [11] and Frontoso et al. [12] who reported a clear and marked resistance of microorganisms to gentamicin. This may be revealed upon our results where the first estrous conception was $0 \%$. Moreover, Ricketts [13] mentioned that gentamicin inhibits 
leucocyte phagocytosis in vitro and are therefore best avoided for intra-uterine use, unless specifically indicated.

The results of 3rd group (Cefepime) demonstrated that the number of cured mares that return to its normal fertility life was 14 (conception rate was $87.5 \%)$. The first estrous conception rate was $12.5 \%$, the second estrous conception rate was $12.5 \%$ and the third estrous conception rate was $62.5 \%$. The number of mares that retain their pregnancy was 12 (pregnancy rate was 75\%). There were a significant difference between endometritis (control group) and treatment with cefepime $(\mathrm{P}<0.05)$. These results were similar to that reported by Shivamurthy et al. [14] in human that attributed these results to the broad spectrum effect of cefepime.

The results of 4th group (ceftiofur) explained that the number of cured mares that return to its normal fertility life was 14 (conception rate was $70 \%$ ). The first estrous conception rate was $55 \%$, the Second estrous conception rate was $15 \%$ and the third estrous conception rate was $0 \%$. The number of mares that retain their pregnancy was 12 (pregnancy rate was 60\%). The treatment conception interval was (13.75 \pm 8.821$)$. This was approved by Witte et al [15] and Scofield et al. [16] who reported that Ceftiofur crystalline free acid (CCFA) reaches appropriate endometrial tissue values to exceed the minimum inhibitory concentration (MIC) of Streptococcus equi zooepidemicus and Escherichia coli (a common cause of bacterial endometritis) which is the lowest concentration of drug required to inhibit the growth of a bacterial isolate for up to 6 days. Therefore, CCFA could be effective in the treatment of equine bacterial endometritis caused by $S$. zooepidemicus and other susceptible bacterial pathogens in the mare. In conclusion, Cefepime is the most appropriate drug used for treatment of endometritis in mares.

\section{References}

1. Blanchard TL, Varner DD, Schumacher J, Love CC, Brinsko SP, et al. (2003) Endometritis, Manual of Equine Reproduction (2ndedn) Philadelphia: Mosby: 59-68.

2. Ley WB (2004) Infectious causes of endometritis and treatment options, Brood mare reproduction for the equine practitioner. (1stedn) (Made easy series, Jackson Wyo.) Tenton new media: pp. 162-178.
3. Causey RC (2007) Uterine therapy of mares with bacterial infections, Current therapy in equine reproduction. (1st edn), Saunders pp. 105-115.

4. Brinsko SP, Rigby SL, Susceptible Varner DD, Blanchard TL (2003) A practical Method for Recognizing Mares to Post breeding Endometritis. American Association of Equine Practitioners, New Orleans 49: 363-365.

5. Kawthalkar SM (2010) Staining of blood smear. Essential of clinical pathology (1st Edn) Jaypee brothers medical publishers, New Delhi pp. 202.

6. LeBlanc MM (2010) Advances in the diagnosis and treatment of chronic infectious and post-mating-induced endometritis in the mare. Reprod Domest Anim 45 Suppl 2: 21-27.

7. SAS (1987) Statistical Analysis System. User's Guide Statistics; SAS institute, Cary, North Carolina.

8. Troedsson MHT (1997) Therapeutic considerations for mating induced endometritis. Pferdeheilkunde 13: 516-520.

9. Cohen ML (1992) Epidemiology of drug resistance: implications for a post-antimicrobial era. Science 257: 1050-1055.

10. Gibbons A (1992) Exploring new strategies to fight drug-resistant microbes. Science 257: 1036-1038.

11. Siu LK (2002) Antibiotics: action and resistance in gram-negative bacteria. J Microbiol Immunol Infect 35: 1-11.

12. Frontoso R, De Carlo E, Pasolini MP, van der Meulen K, Pagnini U, et al. (2008) Retrospective study of bacterial isolates and their antimicrobial susceptibilities in equine uteri during fertility problems. Res Vet Sci 84: $1-6$.

13. Ricketts SW (1999) The treatment of equine endometritis in stud farm practice. Pferdeheilkunde 15: 588-593.

14. Shivamurthy HM, Himgire JR, Amrutha K, Giridhar (2013) Case controlled Clinical study of Prophylaxis with a single dose of cefepime for caesarean section. J Pub Health Med Res 1: 81-85.

15. Witte TS, Bergwerff AA, Scherpenisse P, Drillich M, Heuwieser W (2010) Ceftiofur derivates in serum and endometrial tissue after intramuscular administration in healthy mares. Theriogenology 74: 466-472.

16. Scofield D, Black J, Wittenburg L, Gustafson D, Ferris R, et al. (2014) Endometrial tissue and blood plasma concentration of ceftiofur and metabolites following intramuscular administration of ceftiofur crystalline free acid to mares. Equine Vet J 46: 606-610. 